\title{
Removal of Suspended Solids Using Pumice Stone in Integrated Fixed Film Activated Sludge Process
}

\author{
Diala Shehab $^{* 1} \quad$ Ghassan durra Al Haddad $^{* 2} \quad$ Mahmoud Hadid $^{* 3}$
}

Department of Environmental Engineering, Faculty of Civil Engineering, Damascus University, Damascus, Syria.

*Corresponding author: eleipjahew@ hotmail.com*, dr.ghassandurrahaddad@gmail.com,mahmoudhadid@yahoo.com

*ORCID ID: https://orcid.org/0000-0003-2946-0388*

Received 23/7/2020, Accepted 27/9/2020, Published Online First 6/12/2020, Published 1/3/2021

This work is licensed under a Creative Commons Attribution 4.0 International License.

\begin{abstract}
:
Wastewater treatment plants operators prefer to make adjustments because they are more cost effective, to use the existing tank instead of building new ones. In this case an imported materials would be used as bio-loads to increase biomass and thus maintain efficiency as the next organic loading increases.In the present study, a local substance "pumice stone" was used as a biological carrier in the aeration tank, and the experiments were carried out in five stages: without biological carriers, filling ratio of $4 \%, 10 \%, 20 \%$, and $25 \%$ with pumice stone, the maximum organic loading at each stage $(1.1884,1.2144,1.9432,2.7768$, 3.3141)g BOD /.d respectively.Other experiments were carried out to determine the best filling ratio, the SS removal ratio was $(67.57 \%, 69.5 \%, 79.44 \%, 89.61 \%$, and $99.2 \%)$ when the filling ratio with pumice stone was $(0,4,10,20$, and 25$) \%$ respectively, at organic loading $2 \pm 0.0528 \mathrm{~g}$ BOD /l.d, so the best filling ratio of pumice stone was $25 \%$.
\end{abstract}

Key words: Activated sludge, Biological Carriers, Pumice Stone, Suspended Solid.

\section{Introduction:}

Sewage treatment plants are designed for a period of (25-30) years, and at the end of it, engineering procedures must be taken to preserve the plant's output due to the increased organic loading coming to the plant.

These procedures are:

Either the horizontal expansion of the treatment plant units (i.e. building new treatment units) and this procedure requires a high cost, or technical procedure to increase the biomass without adding new units.

At the present time, it is preferable for the sewage treatment plants to make modifications because they are more cost-effective, as they use the existing tank instead of building new tanks.

The combined modification of the conventional activated sludge process uses suspended or fixed media of a suitable material, which acts as carriers for the growth of active biomass on its surface, and this is called the IFAS system(1).

An integrated fixed-film activated sludge (IFAS) system is one of the most popular modified activated sludge processes which increases the microbial population and accelerates the biodegradation of organic compounds by adding a fixed media to a suspended growth basin (1).

This process is actually an integration process which includes the suspended and attached growth and provides the advantages of both attached and suspended growth systems (2).

The IFAS process has many advantages in comparison with conventional processes of the activated sludge. This system provides more resistance against organic and hydraulic shock load; besides, it has more flexibility and higher efficacy than other activated sludge processes $(3,4)$

The IFAS system is a good option to upgrade the Activated Sludge System especially in case of facing scarcity of land and provides higher removal efficiency of COD and nutrients relative to conventional activated sludge. It also possesses a lower retention time, higher hydraulic load, and less tank volume $(5,6)$.

In the present study, a local substance "pumice stone" with a surface specificity of $224 \mathrm{~m}^{2} / \mathrm{m}^{3}$ was used as a fixed biological carrier in the aeration tank over 253 days, with different filling ratio of $0 \%$, $4 \%, 10 \%, 20 \%$, and $25 \%$ when the organic loading 
changed from $0.92 \pm 0.0384$ to $3.4 \pm 0.0706 \mathrm{gBOD} /$ l.d.

While in a previous study, moving plastic holders of type PVC with a surface specificity of $350 \mathrm{~m} 2 / \mathrm{m} 3$ was used with a filling ratio of $25 \%$ with increasing the organic loading inside the experimental plant over 105 days, the best removal ratio of SS was $85.24 \pm 3.21 \%$ when the organic loading was 0.44 gCOD / 1.d ..(7)

In another study ,Moving Bed Biofilm Reactors (MBBR) was used to rehabilitate a sewage plant in
Kiththal city, India, samples at inlet and outlet during the period from January 2014 to April 2014 were collected, the SS removal ratio was $83.11 \%$.. (8)

Six full-scale IFAS were surveyed to quantify Trace organic contaminants and estrogenic activity removal, the type of media varies for each IFAS, it is shown in Table 1, all of them performed well in terms of the removal of TSS (91- 99\%).(9).

Table1. Characteristics of surveyed wastewater treatment plants (WWTPs). (9).

\begin{tabular}{cccccccccc}
\hline $\begin{array}{c}\text { WWTP } \\
\text { ID }\end{array}$ & $\begin{array}{c}\text { Sample } \\
\text { Date (in } \\
\text { 2015) }\end{array}$ & $\begin{array}{c}\text { IFAS } \\
\text { Install } \\
\text { Date }\end{array}$ & $\begin{array}{c}\text { Design } \\
\text { Capacity } \\
(\text { MGD) }\end{array}$ & $\begin{array}{c}\text { Median } \\
\text { Flow } \\
\text { (MGD) }\end{array}$ & $\begin{array}{c}\text { SRT }^{\mathrm{b}} \\
(\mathrm{d})\end{array}$ & $\begin{array}{c}\text { Aerobic }_{\mathrm{SRT}^{\mathrm{c}}} \\
(\mathrm{d})\end{array}$ & $\begin{array}{c}\text { Temp }^{\mathrm{d}} \\
\left({ }^{\circ} \mathrm{C}\right)\end{array}$ & $\begin{array}{c}\text { Carrier } \\
\text { IFAS Media Type }\end{array}$ & $\begin{array}{c}\text { Media } \\
\text { Filling Ratio }\end{array}$ \\
\hline A & $24-$ Sep & 2013 & 0.15 & 0.05 & 12.4 & 6.7 & 21.6 & AnoxKaldnes K5 & 0.35 \\
B & 30-Oct & 2010 & 7.5 & 2.5 & 9 & 6 & 19.7 & Active Cell 450 & 0.35 \\
C & 14-Oct & 2013 & 10.7 & 6.4 & 17.5 & 8.8 & 23 & Active Cell 450 & 0.50 \\
D & $27-$-Oct & 2011 & 15 & 9.3 & 6.7 & 4.3 & 17.5 & BiofilmChip $^{\text {TM }}$ p & 0.38 \\
E & 16-Oct & 2013 & 23.2 & 11.5 & 9.9 & 5.1 & 21.5 & AnoxKaldnes K1/K3 & $0.50 / 0.67$ \\
F & 8-Oct & 2013 & 50 & 32.2 & 9.1 & 4.4 & 20.8 & AnoxKaldnes K3 & 0.52 \\
\hline
\end{tabular}

\section{Materials and Methods:}

The experiments were conducted at the sewage plant in Homs, Syria, over 253 days.

The operation was started on July 1, 2018 using aerated sludge from wastewater treatment plant in Dweir, Homs, Syria which is a plant that works with conventional activated sludge technology, to accelerate the formation and growth of biomass. The wastewater used to accomplish this research was brought from the outlet of the first sedimentation tank.

The characteristics of the wastewater and sludge which were taken from Homs wastewater treatment plant, are shown in Table(2):

Table 2. Characteristics of wastewater and sludge of Homs wastewater treatment plant.

\begin{tabular}{lll}
\hline Biological Oxygen Demand & BOD $_{5}$ & $191.7 \mathrm{mg} / \mathrm{l}$ \\
\hline Suspended Solids & $\mathrm{SS}$ & $202 \mathrm{mg} / \mathrm{l}$ \\
$\begin{array}{l}\text { Mixed Liquid Suspended } \\
\text { Solids in Aeration Tank }\end{array}$ & MLSS $_{\text {AT }}$ & $2988 \mathrm{mg} / 1$ \\
Sludge Retention Time & SRT & $4-5$ days \\
\hline
\end{tabular}

The pumice stone is considered chemically inert due to its high content of Silicon dioxide, $\mathrm{SiO}_{2}$ $=75 \%$.

The black basalt pumice stone with a specific weight $=1.2 \mathrm{gr} / \mathrm{cm}^{3}$, was used in this study.

The pumice stone was prepared in a cylindrical shape with dimensions $\mathrm{D}=2.5 \mathrm{~cm}, \mathrm{H}=$ $1 \mathrm{~cm}$, and the specific surface measurement was $224 \mathrm{~m}^{2} / \mathrm{m}^{3}$.

The pumice stone was fixed on a metal holder.
The percentage of filling of fixed biological carriers is calculated by dividing the size of the outer frame of the holder of the biological carriers are fixed on it, by the effective tank size ... (10) Effective aeration tank volume $=10$ liters Single holder size $=122.7185 \mathrm{~cm}^{3}=0.123$ liters

The OLR (Organic Loading Rate) of the experimental plant was changed by mixing the water from the sedimentation with a percentage of the water entering the Homs wastewater treatment plant.

\section{-Pilot plant components:}

The experimental tank was manufactured according to studies conducted by many researchers...(11,12)

Fig (1) shows the components of the experimental plant used in the experiments, which consist of the following:

1- 50liters wastewater collection tank, from which the water was transferred to the aeration tank with a flow of 2 liters / hour " $\mathrm{Q}_{\mathrm{AT}}=2 \mathrm{l} / \mathrm{h}$ ".

2- Aeration tank, cylindrical in shape $\mathrm{D}=20 \mathrm{~cm}, \mathrm{H}$ $=33 \mathrm{~cm}$, where the effective tank volume is 10 liters " $\mathrm{V}_{\mathrm{AT}}=10 \mathrm{~L}$ ", it means the Hydraulic Retention Time (HRT) in aeration tank was 5 hours: "HRT $=\mathrm{V}_{\mathrm{AT}} / \mathrm{Q}_{\mathrm{AT}} "$.

The tank was equipped with a compressed air system located at the bottom of the tank, with dissolved oxygen value more than $2 \mathrm{mg} / \mathrm{l}$. Water enters the tank by flowing from the collecting tank to the secondary sedimentation tank 
3- Secondary sedimentation tank, cylindrical with dimensions $\mathrm{D}=20 \mathrm{~cm}, \mathrm{H}=30 \mathrm{~cm}$, which has in it a sludge collection funnel with height $\mathrm{H}=15 \mathrm{~cm}$.

The treated wastewater collected on the surface is transferred to the treated water tank

4- The sludge return pump: to transfer returned activated sludge "RAS" from the bottom of the secondary sedimentation tank to the aeration tank, tank with a flow of 2 liters / hour " $\mathrm{Q}_{\mathrm{RAS}}=2 \mathrm{l} / \mathrm{h}$ ", which means the recycle ratio was $100 \%$.

5- Treated water tank: The treated water is collected in this tank.

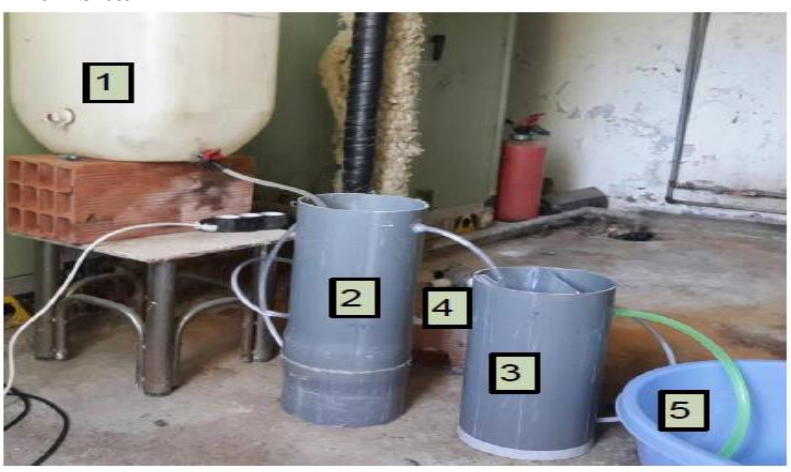

Figure 1. The experimental plant used for experiments

Fig(2) shows the schematic diagram of the experimental plant used in the experiments

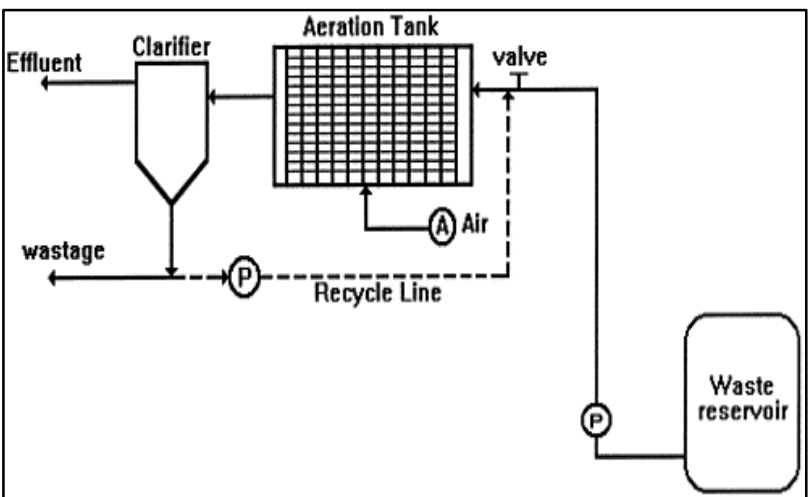

Figure 2. The schematic diagram of the experimental plant used in the experiments

The concentration of the biomass MLSS in aeration tank and the SS concentration of the treated wastewater from the secondary sedimentation tank were measured in the lab of Homs wastewater treatment plant in Dweir, Homs, Syria

\section{Results and Discussion:}

First: The experiments were carried out in stages: without biological carriers, and by adding pumice stone with different filling ratios, all stages are shown in Table (3), the pumice stone filling ratio increased when the SS removal decreased to less than $83 \%$.

Table 3. SS removal ratio and MLSS concentration when changing the organic loading with different pumice stone filling ratio.

\begin{tabular}{|c|c|c|c|c|c|}
\hline pumice stone filling ratio & operation time & OLR & Removal of SS & MLSS & $\mathrm{F} / \mathrm{M}$ \\
\hline$\%$ & day & g BOD /l.d & $\%$ & $\mathrm{~g} / 1$ & $\mathrm{~g} \mathrm{BOD} / \mathrm{g}$ Total MLSS $\mathrm{AT}_{\mathrm{AT}} \mathrm{d}$ \\
\hline \multirow{4}{*}{0} & $15-22$ & $0.92 \pm 0.0384$ & 90.71 & 2.988 & 0.308 \\
\hline & $23-29$ & $0.99 \pm 0.0288$ & 89.23 & 3.176 & 0.312 \\
\hline & $30-36$ & $1.05 \pm 0.024$ & 86.07 & 3.308 & 0.317 \\
\hline & $37-43$ & $1.15 \pm 0.0384$ & 82.86 & 3.392 & 0.339 \\
\hline \multirow{5}{*}{4} & $58-64$ & $1.15 \pm 0.0384$ & 84.69 & 3.6085 & 0.319 \\
\hline & $65-71$ & $1.15 \pm 0.0384$ & 84.78 & 3.6225 & 0.317 \\
\hline & $72-78$ & $1.15 \pm 0.0384$ & 84.96 & 3.6958 & 0.311 \\
\hline & $79-85$ & $1.2 \pm 0.0144$ & 82.93 & 3.7598 & 0.319 \\
\hline & $86-92$ & $1.25 \pm 0.024$ & 80.36 & 3.7898 & 0.330 \\
\hline \multirow{7}{*}{10} & $93-99$ & $1.25 \pm 0.024$ & 87.66 & 4.529 & 0.276 \\
\hline & $100-106$ & $1.25 \pm 0.024$ & 90.38 & 4.544 & 0.275 \\
\hline & $107-113$ & $1.25 \pm 0.024$ & 91.59 & 4.570 & 0.274 \\
\hline & $114-120$ & $1.4 \pm 0.0528$ & 93.82 & 5.220 & 0.268 \\
\hline & $121-127$ & $1.5 \pm 0.144$ & 95.27 & 6.613 & 0.227 \\
\hline & $128-134$ & $1.6 \pm 0.048$ & 96.15 & 7.428 & 0.215 \\
\hline & $135-141$ & $1.8 \pm 0.0432$ & 88.56 & 6.667 & 0.270 \\
\hline \multirow{9}{*}{20} & $149-155$ & $2 \pm 0.0528$ & 88.26 & 6.474 & 0.309 \\
\hline & $156-162$ & $2 \pm 0.0528$ & 89.34 & 6.498 & 0.308 \\
\hline & $163-169$ & $2 \pm 0.0528$ & 91.23 & 6.580 & 0.304 \\
\hline & $170-176$ & $2.1 \pm 0.0408$ & 92.82 & 6.961 & 0.302 \\
\hline & $177-183$ & $2.25 \pm 0.048$ & 96.85 & 7.493 & 0.300 \\
\hline & $184-190$ & $2.4 \pm 0.072$ & 94.17 & 7.808 & 0.307 \\
\hline & $191-197$ & $2.55 \pm 0.0624$ & 92.55 & 8.160 & 0.312 \\
\hline & $198-204$ & $2.7 \pm 0.0768$ & 90.13 & 8.556 & 0.316 \\
\hline & $205-211$ & $2.85 \pm 0.0624$ & 80.45 & 8.825 & 0.323 \\
\hline \multirow{6}{*}{25} & $212-218$ & $2.85 \pm 0.0624$ & 89.17 & 9.3677 & 0.304 \\
\hline & $219-225$ & $2.85 \pm 0.0624$ & 90.45 & 9.6066 & 0.297 \\
\hline & $226-232$ & $2.85 \pm 0.0624$ & 92.28 & 9.7535 & 0.292 \\
\hline & $233-239$ & $3 \pm 0.0744$ & 90.62 & 10.1712 & 0.295 \\
\hline & $240-246$ & $3.2 \pm 0.1141$ & 88.9 & 10.2159 & 0.313 \\
\hline & $247-253$ & $3.4 \pm 0.0706$ & 80.12 & 10.3275 & 0.329 \\
\hline
\end{tabular}


The organic loading increased over periods starting from the beginning of the experimental plant.

SS was measured for five samples per week for the wastewater coming from the secondary sedimentation in the experimental plant and the removal percentage was calculated.

MLSS was also measured in the experimental aeration tank.

The number 15 means 15 days from the start of operation, and the period (15-22) indicates that the organic loading in this period was almost constant and the yield also. As for the subsequent periods, the loading increased and the yield decreased and became lower than $83 \%$.

Fig (3), (4), (5), (6), and(7) show the effect of the change in the organic loading rate on removal SS when using pumice stone with a filling ratio 0,4 , $10,20,25 \%$, respectively.

The maximum organic loading rate was (1.1884, $1.2144,1.9432,2.7768,3.3141) \mathrm{g}$ BOD /l.d, at each stage.

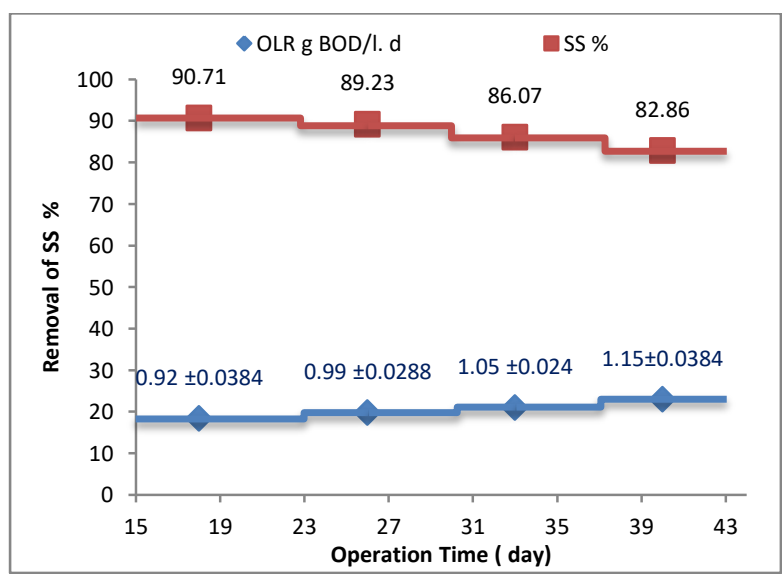

Figure 3. Effect of OLR change on SS removal

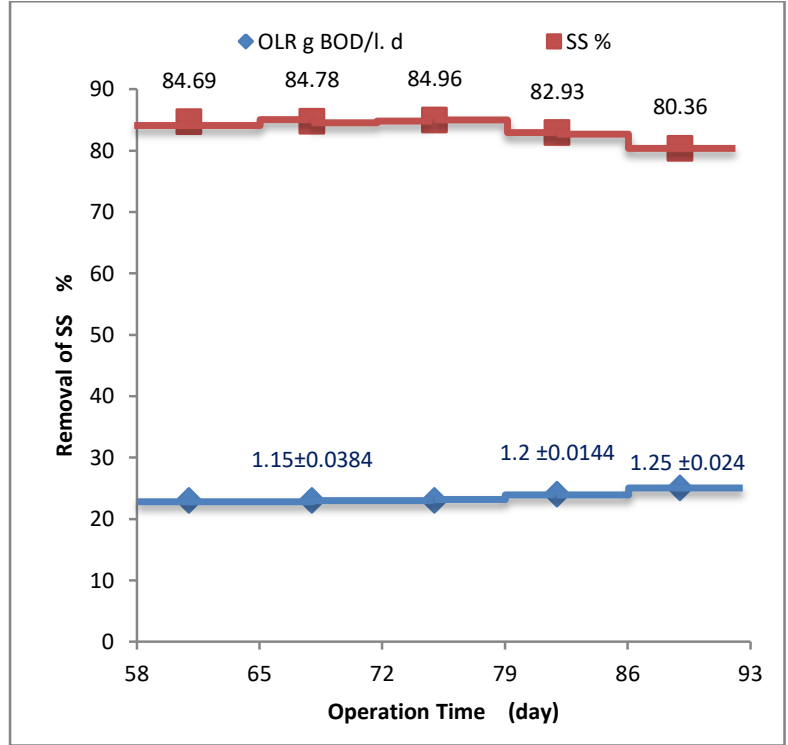

Figure 4. Effect of OLR change on SS removal when using pumice stone at $4 \%$ filling ratio.

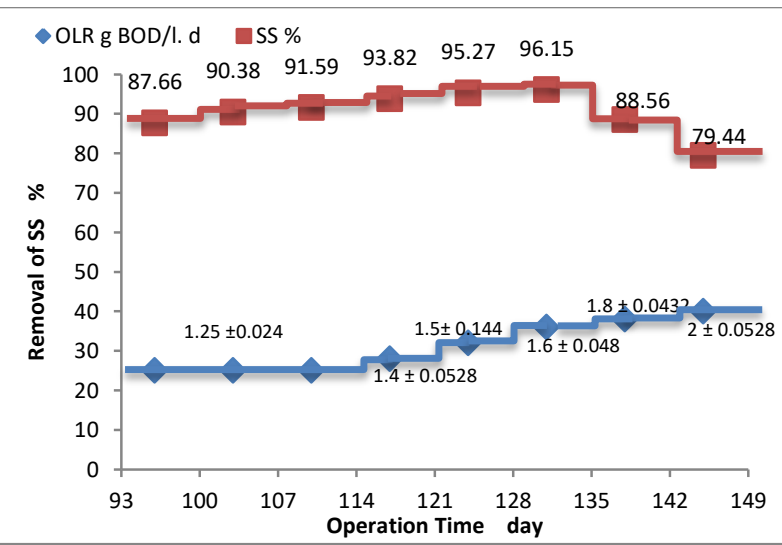

Figure 5. Effect of OLR change on SS removal when using pumice stone with $10 \%$ filling ratio.

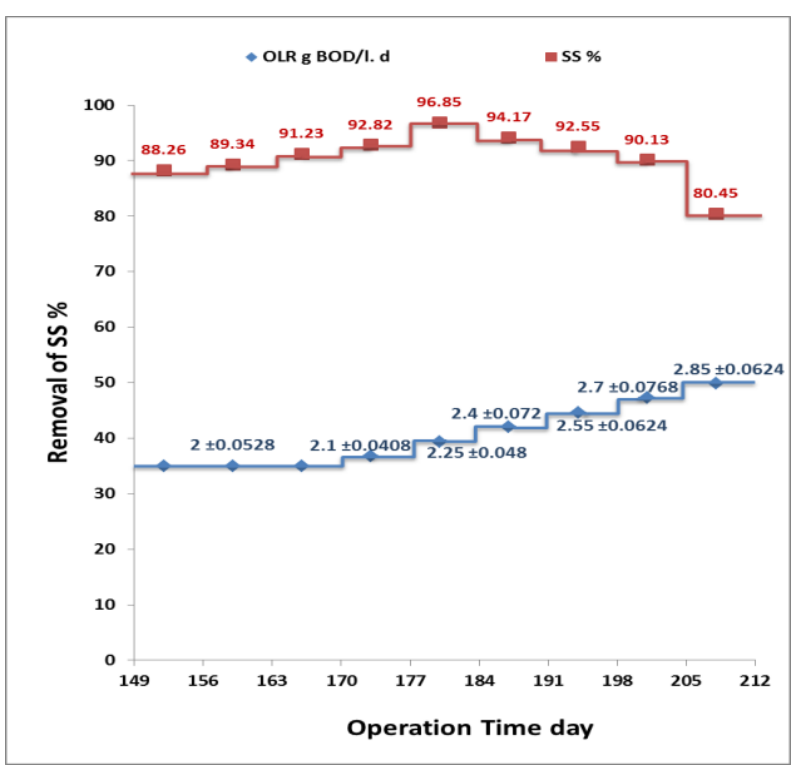

Figure 6. Effect of OLR change on SS removal when using pumice stone with $20 \%$ filling ratio. 


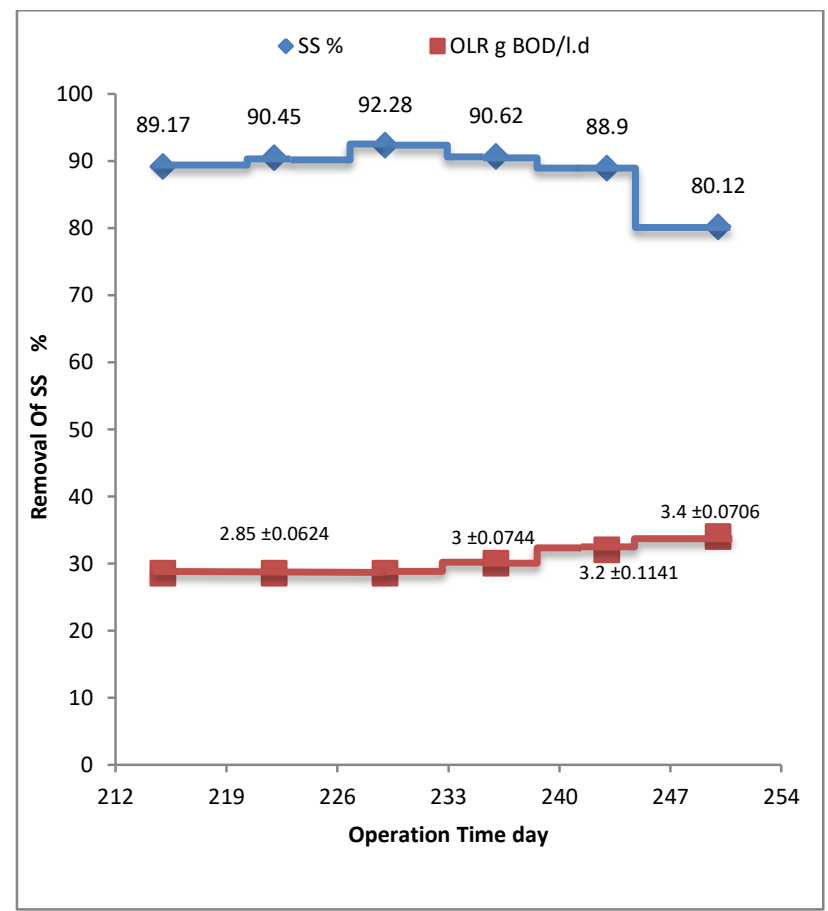

Figure 7. Effect of OLR change on SS removal when using pumice stone with $25 \%$ filling ratio.

The yield decreases due to the increase of organic loading rate with slightly increase of biomass.(6)

Second: Experiments were carried out to determine the best pumice stone filling ratio at the same OLR. The SS removal ratio was $(67.57 \%$, $69.5 \%, 79.44 \%, 89.61 \%$, and $99.2 \%$ ) when the filling ratio with pumice stone was $(0,4,10,20$, and 25$) \%$ respectively, at organic loading $2 \pm 0.0528 \mathrm{~g}$ BOD /l.d.

Figure(8) shows the removal of SS with different pumice stone filling ratio, when OLR was 2 $\pm 0.0528 \mathrm{~g} \mathrm{BOD} / 1 . \mathrm{d}$.

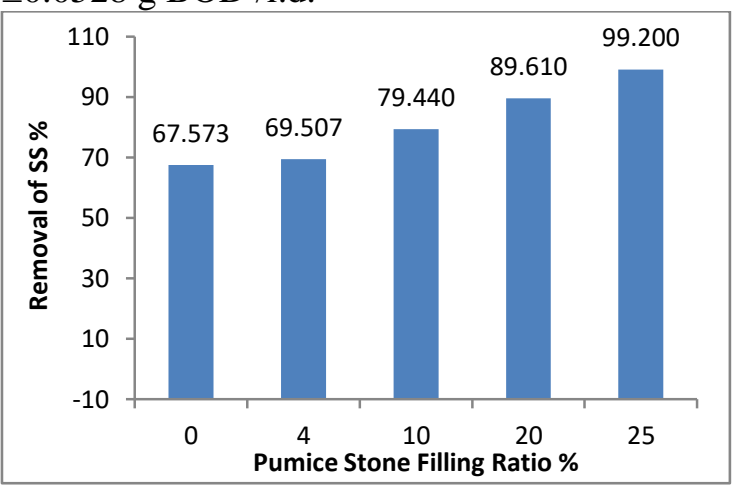

Fig 8. Removal of SS with different pumice stone filling ratio

In a previous study, the best removal ratio of SS was $85.24 \pm 3.21 \%$ when the organic loading was $0.44 \mathrm{gCOD} / 1 . \mathrm{d} .(8)$

In another study the removal of TSS was (91- 99\%).(9).Comparing the results of different studies with those of the present study revealed that the IFAS system has had high efficiency in TSS removal which might be due to the fixed media of the biological reactor.

Indeed, hybrid systems like IFAS create the conditions of attached and suspended biological growth, and thereby the sludge sedimentation capability improves, so suspended solids along with the sludge are deposited faster with better conditions.(1)

\section{Conclusion:}

In this study, the following conclusions are obtained:

1- The maximum organic loading rate is (1.1884, $1.2144,1.9432,2.7768,3.3141) \mathrm{g}$ BOD /1.d, when the filling ratio with pumice stone is $(0,4,10,20$, and 25$) \%$ respectively, to obtain the yield equal and more than $83 \%$.

2- The SS removal ratio is $(67.57 \%$, $69.5 \%, 79.44 \%, 89.61 \%$, and $99.2 \%$ ) when the filling ratio with pumice stone is $(0,4,10,20$, and 25$) \%$ respectively, at organic loading $2 \pm 0.0528 \mathrm{~g}$ BOD /l.d, so the best filling ratio of pumice stone is $25 \%$.

Table of terms:

\begin{tabular}{lll}
\hline MBBR & Moving Bed Biofilm Reactors \\
BOD & Biological Oxygen Demand & \\
SS & Suspended Solids & \\
MLSS & Mixed Liquid Suspended Solids & \\
IFAS & Integrated Fixed-Film Activated & Sludge \\
F/M & Process & \\
\hline
\end{tabular}

\section{Authors' declaration:}

- Conflicts of Interest: None.

- We hereby confirm that all the Figures and Tables in the manuscript are mine ours. Besides, the Figures and images, which are not mine ours, have been given the permission for republication attached with the manuscript.

- Ethical Clearance: The project was approved by the local ethical committee in Damascus University.

\section{References:}

1. Kim H-s, Gellner JW, Boltz JP, Freudenberg RG, Gunsch CK, Schuler AJ. Effects of integrated fixed film activated sludge media on activated sludge settling in biological nutrient removal systems. Water Res 44:1553-1561; 2010.

2. Mehrdadi N, Azimi A, Bidhendi GN, Hooshyari B . Determination of design criteria of an H-IFAS reactor in comparison with an extended aeration activated sludge process; 2007.

3. Regmi P, Thomas W, Schafran G, Bott C, Rutherford B, Waltrip D. Nitrogen removal assessment through 
nitrification rates and media biofilm accumulation in an IFAS process demonstration study. Water Res 45:6699-6708; 2011.

4. Rosso D, Lothman SE, Jeung MK, Pitt P, Gellner WJ, Stone AL, Howard D. Oxygen transfer and uptake, nutrient removal, and energy footprint of parallel fullscale IFAS and activated sludge processes. Water Res 45:5987-5996; 2011.

5. Andreottola G, Foladori P, Gatti G, Nardelli P, Pettena M, Ragazzi $M$. Upgrading of a small overloaded activated sludge plant using a MBBR system. J Environ Sci Health A 38:2317-2328; 2003.

6. Eslami H, Samaei MR, Shahsavani E, Ebrahimi AA . Biodegradation and fate of linear alkylbenzene sulfonate in integrated fixed-film activated sludge using synthetic media. Desalin Water Treat 92:128133; $2017 \mathrm{~b}$.

7. Eslami et al," Biodegradation and nutrients removal from greywater by an integrated fixed-film activated sludge (IFAS) in different organic loadings rates" . AMB Expr 8:3; 2018.https://doi.org/10.1186/s13568017-0532-9

8. Pipraiya, A. Performance Evaluation of Wastewater Treatment Plant Based on MBBR Technology- A Case Study of Kaithal Town, Haryana (India):
M.Tech Department of Civil Engineering, National Institute of Technology Kurukshetra Haryana, India; 2014.

9. Michael J. Shreve, Rachel A. Brennan,Trace organic contaminant removal in six full-scale integrated fixed film activated sludge (IFAS) systems treating municipal wastewater". Water Res.151 (2019) 318e331; 2019.www.elsevier.com/locate/waters

10. Sen.D,et al. Successful Evaulation Of Ten Ifas And Mmbr Facilities By Applying The Unified Model To Quantify Biofilm Surface Area Requirements For Nitrificaiton, Determine Its Accuracy In Prediciting Effluent Characteristics, And Underholder The Contribution Of Media Towards Organics Removal AndNitrification: Water Environment Foundation; 2006.

11. Mortazavi S.B. , Khavanin A. , Moussavi G. and Azhdarpoor A. Removal of Sodium Dodecyl Sulfate in an Intermittent Cycle Extended Aeration System: 11(2), 290-293; 2008.

12. Mota C. , Melanie A.H., Ridenoure J.A., Cheng J.J. and Reyes F.L. Effects of Aeration Cycles on Nitrifying Bacterial Populations and Nitrogen Removal in Intermittently Aerated Reactors:APPL ENVIRON MICROB, 71 (12), 8565-8572; 2005.

\section{إزالة المواد المعلقة SS باستخدام حجر الخفان في نظام الحمأة المنشطة المشترك}

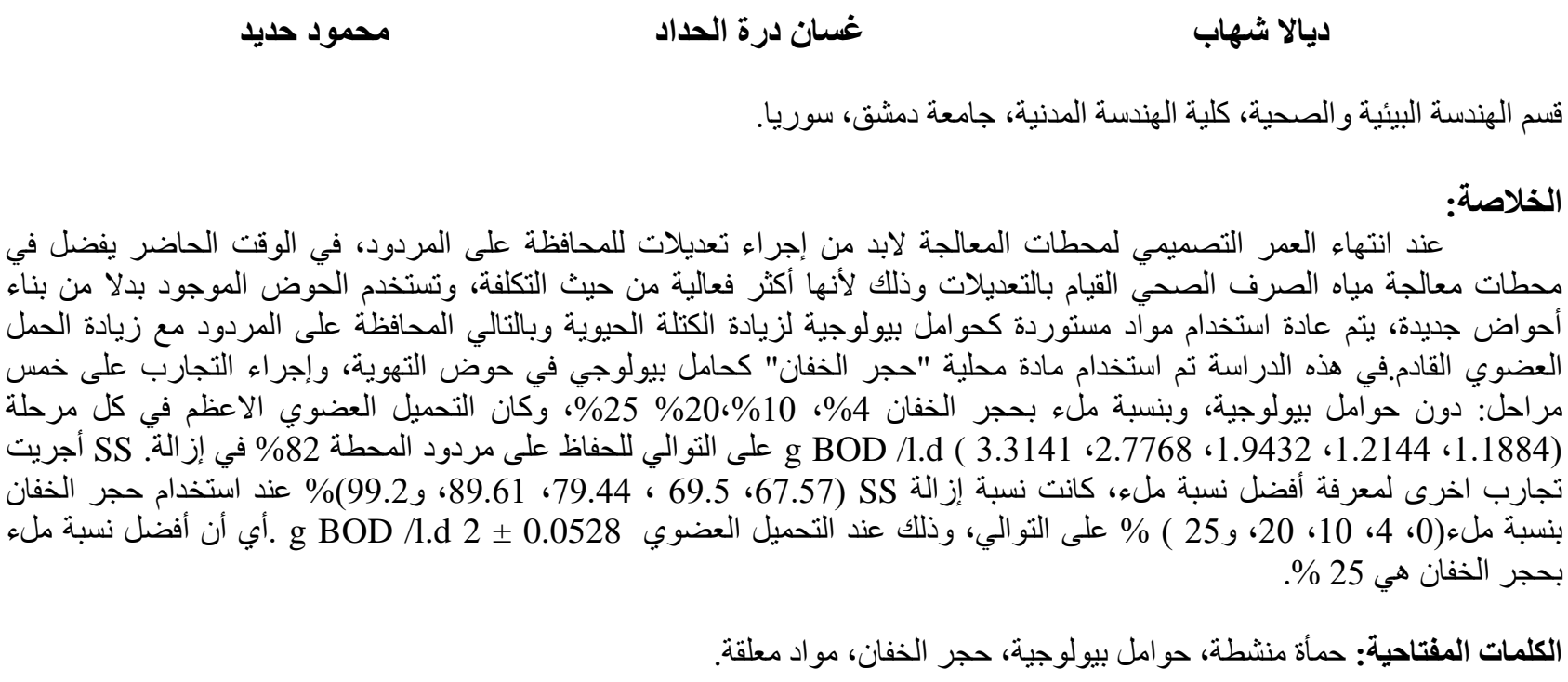

